\title{
Kırgız Halkının Bağımsızlık İsyanı: 1916 Ürkün*
}

\author{
Independence Revolt of the Kyrgyz People: Ürkün, 1916
}

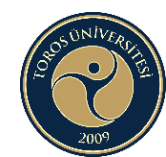

Murat KÜTÜKÇ $\ddot{U}^{1}$

\section{$\ddot{O} \mathbf{z}$}

Rus Çarlığı, 19. Yüzyılın ikinci yarısından itibaren Türkistan bölgesinde siyasi ve etnik asimile politikalarında önemli değişikliler yapmaya başlamıştı. Dolayısıyla Rus Çarlığı Kırgızistan Halkı üzerindeki hâkimiyeti için bölgedeki askeri gücünü artırmakla beraber, Rus yerleşimcileri bölgeye yerleștirmeye başlamıştır. Kırgızistan'da toprağa el koyma işleri 1907'de “Kırgızları Yerleştirme" ve 1908`de "Yedi Su Bölgesini Koloni Yapma" kararlarını uygulamaya başlamıştır. Bu kararların dayanağı "Step Kanunu”nun “Göçebelerin Topraklarını Devlet Mülkiyetine Geçirmesi” başlıklı 119. maddesiydi. Ancak Kırgızlar bu durumdan rahatsız olduklarını her durumda Rus yönetimine bildirmislerdir. Türkistan bölgesinin Genel Valisi A. N. Kuropatkin bu meseleyi Rus Çar'ına götürmüş, ancak hiçbir sonuç alamamıştır. Diğer taraftan, Rus Çarlığı yöneticileri sorunları çözmeye gayret etmemişlerdir. Hatta bu yöneticilerin arasında Kırgız ayaklanmasının şiddetli bir şekilde gerçekleşmesini isteyenler de vardı. Onlara göre Kırgızların isyanı sonrası yerlerinden sürülecek isyancılardan boşalmış topraklar Rus yerleşimcilere açılacaktı. 1916 yılında başlayan büyük isyanda yüzbinlerce Kırgız Türkü şehit düşmüş, yüz binlercesi ülkelerinden sürgün edilmiş, Çin'e göçmek zorunda kalmıştır. Rusya'daki iktidar değişikliği, Orta Asya'daki Türk toplumlarının bağımsız devlet kurma isteklerini gerçekleștirmelerine geçici olarak imkân vermiş, ancak yayılımcı Rus politikası, daha sonra buralardaki bağımsızlık oluşumlarını bastırarak, bütün toplulukları kendisine bağlamıştır. Çalışmanın konusu, Kırgız Türklerinin bağımsızlık mücadelesinin ağır bir bedeli olan Ürkün Katliamı'nı ve sonrası araştırmaktır.

Anahtar Kelimeler: Bağımsızlık, İsyan, Ürkün, Katliam, Kırgız Halkı.

\section{Abstract}

Since the second half of the 19th century, the Russian Turkestan had begun to make significant changes in its political and ethnic assimilation policies in the Turkestan region. Therefore, the Russian Tsardom increased its military power in the region for its dominance over the people of Kyrgyzstan, the Russian settlers began to settle in the region. Land seizure works in Kyrgyzstan began to implement the decisions of "Settlement of the Kyrgyz" in 1907 and "Making the Yedi Su Region a Colony" in 1908. The basis for these decisions was Article 119 of the "Step Law" titled "Nomads Transfer Their Lands to State Ownership". However, in any case, the Kyrgyz reported that they were uncomfortable with this situation to the Russian administration. The General Governor of the Turkestan region, A. N. Kuropatkin, took this matter to the Russian Tsar, but he could not get any results. On the other hand, contrary to solving the problems of the Russian Tsarist rulers, among these rulers there were those who wanted the Kyrgyz uprising to take place violently. According to them, the vacant lands of the rebels who would be expelled after the Kyrgyz revolt would be opened to the Russian settlers. In the great revolt that started in 1916, hundreds of thousands of Kyrgyz Turks had martyred, hundreds of thousands were driven from their countries and had to migrate to China. The change of power in Russia temporarily had allowed the Turkish communities in Central Asia to realize their desire to establish an independent state, but the expansionist Russian policy later suppressed the independence formations in these regions and tied all communities to themselves. The subject of the study is to investigate the Urkun Massacre and its aftermath, which has a heavy price for the independence struggle of the Kyrgyz Turks.

Keywords: Independence, Revolt, Urkun, Massacre, Kyrgyz People

DOI: $10.54709 /$ iisbf. 1028952

Atıf (to cite): Kütükçü, M., (2021). Kırgız Halkının Bağımsızlık İsyanı: 1916 Ürkün. Toros Üniversitesi İiSBF Sosyal Bilimler Dergisi, 8(15), 1-9.

\footnotetext{
* Bu çalışma 23.11.2021 tarihinde düzenlenen “ístiklal Marşı ’nın Kabulünün 100. Yllı: Türk Kültür Coğrafyasında İstiklal Mücadeleleri Paneli" bildiri olarak sunulmuştur.

${ }^{1}$ Dr., Çă̆ Üniversitesi, muratkutukcu@cag.edu.tr, ORCID: 0000-0003-4311-8036
} 


\section{GİRIŞ}

Kırgızlar, Kuzeydoğu Asya hattında etkinlik gösteren en eski Türk halklarından birisidir. Profesör Gumilev onlar hakkında şu bilgileri vermektedir: Gobi Çölü nün kuzey ve güney tarafını Göktürkler ve Uygurlar yeniden şekillendirirken, steplerin kuzeyinde Kırgızlar bir güç olarak belirginleştiler (Köylü, 2014: 6).

Gök Türk yazıtlarda geçen Türk kavim adları içinde, tarihleri çok eskiye dayanan ve Çin kaynaklarında söylenenlerden biri de Orta Asya ve Sibirya'da yaşayan çeşitli boylardan oluşmuş Kırgız Boyunun adıdır. Kırgız Halkı, diğer tüm Türk boyları gibi Çinlilerle beraber Asya kıtasının en eski halklarındandır. Kırgızlar hakkında ilk tarihi bilgiler "Şí TZí” (Tarihi Yazılar) adlı ilk Çin kaynaklarında yer almaktadır. Kırgızlar, M.Ö.2000’lere kadar dayanan geçmişleriyle dünyanın en eski halklarından biri olduğunu gösterir. Bilinen Kırgız boyları Edirgine, İçkilik, Karatal, Kırkoğlu, Kölpeş, Kuşçu, Manguş, Mundi, Mundus, Muratali, Sarı, Togay, Tazanay, Togayberdi olarak sayılmaktadır (Köylü, 2014: 16).

Gök Türk devletinin yıkılışından sonra Uygur devletinin egemenliğine girmişlerdir. Ancak, Kırgızlar, Uygurlar tarafından uygulanan ağır vergilere karşı isyan ederek, 9. yüzyılın başlarında Uygurlarla yaptıkları bir savaşta büyük kayıp vermelerine rağmen, 839 yılının sonunda Uygur Kağanını öldürerek Türk Devletinin başına geçmiştir (Köylü, 2014: 16). Bu dönemde Kırgızlar, üçüncü Kırgız devleti olan "Büyük Kırgız Khanat Devleti”ni kurmuşlardır. M.S. 9-10. yüzyıllar arasında Kuzey Sibirya, Moğolistan, Baykal, İrtiş, Isık-Göl ve Talas bölgesinde; M.S. 10. yüzyllında Kuzey Sibirya, Altay, Güneybatı Moğolistan bölgesinde; M.S.12. Yüzyllda ise Altay ve Saya bölgesinde egemenliğini sürdüren bu devlet hem önemli askeri başarılar sağlamış hem de Orta Asya ile yoğun ticarette bulunmuştur (Köylü, 2014: 16).

Kırgız Halkı`nı isyana götüren ve Ruslar tarafından sömürgeleştirilmesi olayları 19. yüzyılın ikinci yarısından 20. yüzyılın başına kadar uzanmaktadır. Endüstri devrimiyle askeri alanda güçlenen Rus Yönetimi Kırgızlar üzerinde önemli bir otorite kurarak askeri tedbirlerle ve bölgeye gönderdiği sömürgeci düşünceye sahip Rus Milliyetçisi yöneticiler aracılığ 1 ile hâkimiyeti altına almıştır. Rusya Kırgızlar üzerinde uyguladığı askeri baskının yanı sıra Rus yerleşimcileri de bölgeye göndererek "kolonizasyon" politikasını uygulamaya başlamıştır. Kolonizasyon politikası ile Rus yerleşimcilerin sayısı her geçen sene daha da artırtılmış, nihayetinde "Yedi Su" bölgesini Kolonileştirmek maksadıyla 1908 yılında çıkarttıkları "Step Kanunu"nun 119. maddesine dayanarak göçebe olarak yaşayan Kırgız Halkı'nın taşınmaz mülkiyetleri kamulaştırılarak Rus yerleşimcilere açılmıştır.

Yüzyıla yakın sömürge yönetimleri altında ezilen Kırgız Halkı Birinci Dünya Savaşı ile birlikte Rus Yönetimleri tarafından çıkartılan kanunlarla daha fazla fakirleştirilmeleri, otlak ve topraklarına el konulması ile bu toprakların Rus yerleşimcilere \%58,6 sının verilmesi Kırgız Türklerinin zaman zaman yaşananlara karşı seslerini yükseltmelerine ve ayaklanmasına neden olmuştur. Kırgız halkı Çarlık Rejiminin baskıcı ve sömürge yönetimine karşı $1885^{\prime}$ te Fergana, 1897'de Taşkent'te büyük isyanlar çıkarmışlar, bunlara ek olarak 1900 yılında $75 \mathrm{kez}, 1905$ 'te $235 \mathrm{kez}, 1910$ yılında 334 ve 1915 yılında 372 defa isyan etmişlerdir. 1916 yılına gelindiğinde ise Kırgız tarihine Ürkün Ayaklanması ve Katliamı olarak geçen hadise yaşanmıştır (Kara, 2011: 538).

\section{1. Ürkün Olaylarının Ortaya Çıkış Sebepleri}

Türkistan'daki Huzursuzluğun Temel Tarihsel Nedenleri şu şekilde özetlenebilir:

1. Sebep: Müslümanların hoşnutsuzluğunun temelinde Rusya`nın bölgedeki Türk Halklarını sömürge yönetimiydi. Bu durum Türkistan bölgesindeki Türkleri her zaman rahatsız etmiştir. Zaman zaman bu duruma karşı başlattıkları isyanların Rus Hükümetlerinin kullandıkları "orantısız güç" nedeniyle kanlı 
bir şekilde bastırılması, Rus Yönetimine karşı Müslümanlar arasındaki kin ve düşmanlığı artırmıştır (Kodoman, 2012: 22).

2. Sebep: Anlaşmazlıkların ikinci nedeni, sayısı her geçen gün artan ve Müslümanlara ait Yedi-Su bölgesi gibi verimli topraklara sahip bölgelere göç eden Hıristiyan Rusların ve Rus göçmenlerden oluşan demiryolu işçilerinin bölgeye yerleşimleriydi. Rus hükümetinin düzgün bir yerleşim planlamas1 olmaması dini ve etnik gerilime yol açtı̆̆ gibi, Rus göçmenlerin bölgeye gelmeye başlaması da bir kaos ve kargaşa yarattı. Başlangıçta Rus yerleşimcilerle bölge halkı arasında düşmanca bir durum olmamasına rağmen Rus yetkililerin zamanla Türkistanlıları bereketli topraklardan göçe zorlamaları Müslümanlar arasında kin ve nefret uyandırarak isyanlara neden olmuştur. Dukchi İşhan liderliğinde 1898 yılında Andican bölgesinde başlatılan isyan kanlı bir şekilde bastırılmış, birçok köy boşaltılarak, boşaltılan köylere Rus yerleşimler göç ettirilerek işgal edilmiştir. Bu katliamın ve felaketin anıları hiçbir zaman unutulmamıştır (Kodoman, 2012: 22).

3. Sebep: Rus sömürgecilik politikasının hızla yayıldığ $\mathrm{XX}$. yüzyılın başında Türkistan'da meydana gelen isyanlar nedeniyle Rusya dan getirtilen yerleşimciler ve işçiler, kendilerini ve işgal ettikleri toprakları korumak için Türklere karşı silahlandırılarak yaratılan tehlikeli durum, Müslüman Halk arasında endişe ve korkuya neden olmuştur (Kodoman, 2012: 22).

4. Sebep: Rusya`nın Türkistan bölgesinde aldığı ağır askeri tedbirlerin yanı sıra, bölgede görevlendirdikleri askeri ve sivil bürokratların şiddet, rüşvet alma, yerel halkı soyma ve Türklere ikincil muamele gibi zalimlikleri, Hıristiyan Ruslara karşı kalıcı bir psikolojik düşmanlığın ve Müslüman halkın isyan etmesinin ana nedenlerinden biri olmuştur (Kodoman, 2012: 23).

5. Sebep (Ekonomik nedenler): 20. yüzyılın başlarında Türkistan`da yaşayan halk orta çağdaki gibi besicilikle uğraşan, milli gururu yüksek, fakir, göçebe ve yarı göçebe bir yaşam sürmekteydiler. Göçebe hayatlarının bir parçası olan hayvancılık nedeniyle eski geleneklerine uygun olarak bölgede bir yıl içerisinde dört farklı yerde yaşıyorlardı. Bu çok önemliydi ve vazgeçilmezdi. Ancak Rus yerleşimcilerin bölgeye gelişiyle bu geleneğin yaşatılması zorlaşmıştı. Rus yerleşimcilerin gelmesiyle yazın çıkılan, hayvanların beslendiği yaylaklar ile kışın yaşanılan bölgelere "arazi-çadır" adı altında bir vergi getirilmişti. Ağır bir yük olan bu vergilerin, bölgeye atanan "Manap (feodal bey)"lere yılda iki kez ödenmesi istenmiştir (Kodoman, 2012: 23).

Rus Hükümeti Türkistan Bölgesi'nde, "Türkistan Genel Valisi” yönetiminde sömürge idaresini kurduktan sonra bu bölgeyi bir hammadde pazarı ve deposu olarak görmeye başlamış, bu amaçla bölge halkını geleneksel tarımsal üretimler yerine pamuk üretmeye zorlamışlardır. Ancak pamuk üretimi artarken, pamuk fiyatları önemli ölçüde düşmüştü. Ayrıca üretilen tekstil de Türkistan bölgesindeki Türklere yüksek fiyatlarla satılmaktaydı (Ziyayev, 2007: 357). Ekonomik olarak bu durum Türkistanlıları eskisinden çok daha yoksullaştırmış ve yoksul insanlar topraklarını satmaya başlayınca, topraksız köylülerin sayısı her geçen gün artmaya başlamıştı. Bu sömürü sistemi ve diğer sebepler ile Müslümanların Hristiyan Ruslara yönelik artan nefreti, 1916 yılında isyanın zeminini hazırlamıştır (Kodoman, 2012: 23).

6. Sebep (Pan-Türkizm ve Pan-İslamcıllk'ın Etkisi): Çarlık Rusya'sında yaşayan milli şuura sahip aydınlar bağımsızlığın tek kurtuluş yolu olduğunu görmüşlerdi. Üretilen fikirler önce öğretmenler tarafından yayılmaya başlamış, sonra tüccarlar ve politikacılar arasında da kabul görmüştü. Özellikle 1905 'ten sonra, okullar ve gazeteler bu fikri yaymanın bir yolu olarak kullanıldı.

Bu konuda lider olan Türk Birliği'nin isimleri; "Dil, fikir ve eser birliğì" diyen İsmail Gaspırall, "Üç Tarz-l Siyaset" adlı eseriyle kurtuluş arayan Yusuf Akçura, Azerbaycanlı Ali Hüseyinzade ve Ahmet Ağaoğlu'ydu (Devlet, 1985: 149-160). 
Pan-Türkizm ile paralel gelişen Pan-İslamcılık'la birlikte Türk birliği fikri birçok Türk aydınını da kendine çekmişti. İslamcı aydınlar, bu fikirlerin uygulanmasına engel olarak gördükleri Rus İmparatorluğu'ndan kurtulmak istemişler ve Osmanlı İmparatorluğu'nun yardımıyla birleşik İslam devletini kurmak için Müslüman halk arasında Ruslara karşı propagandaya devam etmişlerdir.

Kısacası Rusya dini, sosyal ve kültürel faaliyetler ile Pan-Türk, Pan-İslamcı fikirleri tehlikeli olarak değerlendirmiş; aydınlar, okullar, öğretmenler, gazeteler, dergiler aracılığıyla yayılmasını polis gücüyle baskılayarak engellemeye çalışmıştır. Bu tür baskılar 1916'ya kadar devam etmiş ancak isyanın patlaması ulusal ve dini bilincin güçlenmesine ve daha da ileri gitmesine neden olmuştur (Kodoman, 2012: 24).

7. Sebep: Rus Çarlığının Rus asıllı sakinleri Türkistan'a yerleştirilmesi, bölgeye açtırdıkları Rus okullarına (Tüzem okulları) Müslüman çocukların kabulü ve Rus dilinde eğitime başlaması Ruslaştırma politikasının en önemli araçlarından biriydi. Arka planda ise "1916'da askere alma emri, bölgesel çapta bir isyanı ateşlemek” için yetmişti (Kodoman, 2012: 24).

Birinci Dünya Savaşı'nda Rusya'daki milyonlarca kişi askere çağrılmıştı. Bunca insanı giydirmek, beslemek ve silahlandırmak için büyük maddî desteğe ihtiyaç vardı. Köylülerin ve şehirdeki işçilerin en verimli yaştakileri harbin kanlı meydanlarına gönderilmişti. Bu olayın tabii bir neticesi de ziraattaki ve sanayideki durma noktasına kadar gelen imalatın süratli düşüşü oldu. Binek hayvanlar asker ihtiyacı için alındığından, hayvanların miktarı da oldukça azaldı. Orduyu beslemek ve silahlandırmak amacıyla hükümet birçok ülkeden borç almak zorunda kaldı.

Benzer olaylar Kırgız topraklarında da yaşanmaktaydı. Rus Çarlı̆̆ı, Birinci Dünya Savaşı`nı bahane ederek bölge halkının mal varlıklarına yönelik şiddetli bir şekilde talan ve zulümlerini arttırmıştır. Bölgede tahıl üretimi ve hayvan besiciliği oldukça azaldığg gibi Rusya dan getirilen tahıl da oldukça azalmıştı. Tüm bu sıkıntıların üzerine savaşı bahane eden Rus Yönetimi vergileri artırmıştı (Brower, 2003: 1). Ayrıca 1915 yılından itibaren yerli halktan bedelli askerlik karşılığ gelirlerinin \%21 kadarını vergi olarak tahsil etmeye başlamıştı (İbraimov, 1993: 224).

Yaşanan bu olaylar neticesinde otlaklarını, sularını ve hayvanlarını kaybeden Kırgız Halkını, açlık ve yoksulluk sonucu ölümler de tüketmeye başlamıştı. Diğer taraftan yaşanan tüm bu sıkıntıları anlatacak, sorunlarına çare olabilecek yetkililerin de olmaması 1916 isyanını oluşturan nedenlerden biri olarak da görülebilir.

Yaşanan zorluklar, yoksulluk, açlık, ölümler ve duyarsız yöneticiler halkın Rus yönetimine karş1 nefretini artırmış ve kurtuluş çareleri aramalarına neden olmuştur.

İsyanı hazırlayan önemli bir gelişme de 25 Haziran 1916 tarihinde Çar II. Nicholas`ın fermanı olarak görülmektedir. Çar bu fermanla; "Imparatorluktaki Rus olmayan erkeklerin hareket halindeki ordu bölgesinde savunma inşaatları ve askeri bağlantı yolları kurulması için yapılmakta olan çalışmalara, aynı zamanda devletin savunması için gerekli olan başka her türlü çalışmalara celp edilmesini" emretmiştir (Djunushaliev, 2002: 627-629). Fermana göre, Türkistan bölgesindeki Sırderya, Fergana, Semerkand, Yettisuv ve Kaspiyartı vilayetlerinde yaşayan 19-43 yaşındaki bütün erkek nüfusun Avrupa cephesi ve gerisinde savaş bölgesinde görev verilmesi gerekiyordu. Türkistan bölgesinde yaşayanlar fermana büyük tepki göstermiş, Rusları temsil eden sembol ve işaretlere saldırarak açıkça düşüncelerini ortaya koymuşlardı (Kara, 2011: 540). Karar 8 Temmuz 1916 yılında yürürlüğe girmiştir. "Ürkün" araştırmacılarından M. Mahmutbekova'nın arşiv kaynaklarına dayanarak verdiği bilgiye göre, “Kırgizistan'ın Prjevalsk kazasından 7150, Narın kazasından 2200, Bişkek kazasından 11530, Talas kazasindan 1794, Kırgızistan'in güneyinden (Oş ve Celal Abad illerinden) 12300 kişi: toplam Kırgızistan'ın bugünkü sınırları dâhilinde 35874 kişsinin bu seferberliğe tabii tutulması gerekiyordu." (Saginbekov, 2007: 32). 
Fermanın halka yayınlanmasıyla Türklerin çoğunlukla yaşadıkları bölgelerde bu durumdan rahatsızlık baş göstermeye başlamıştı. Çeşitli söylentiler, duyumlar zaten zor şartlarda yaşayan halkın sabrını zorlamışt1.

\section{2. Ürkün Olayı}

Birbiriyle bağlantısı olmayan isyanlar, Kırgızistan'da farklı bölgelerde benzer zamanlarda hızla başlamıştır. İsyanlar Çüy, Bişkek, Tokmak, Karakol ve Narın kazalarında şiddetli olarak yoğunlaşmıştı. Bu dönemde (7-15 Ağustos arası) öfkeli Kırgızlar Rus köylerine saldırarak yakıp yıkmışlardır. Fakat bu durumu Kırgızların topraklarını ele geçirmek için bir fırsat gibi gören Rus idareciler isyanların bu şekilde gelişeceğinden haberdardı. İsyanların başlangıç ve devamını tarihsel olarak üç aşamada ele almak gerekir:

- $\quad$ 4-11 Temmuz 1916: Hocent İsyanı (kendiliğinden başlayan ilk isyan)

- $\quad$ 7-28 Ağustos 1916: İsyanların yayılması ve silahlı mücadelenin başlaması.

- $\quad$ Ağustos'un sonu ve Kasım 1916: İsyanların Sonu. Rus Ordusu'nun "Orantısız Güç" kullanarak isyancıları katletmesi ve "Ulu Ürkün (Zorlu Büyük Kaçış)"ın gerçekleşmesi (Sadece Kırgızlar değil bölgede yaşayan Sart Kalmaklar, bazı Dungan köylüleri kısaca kitlesel olarak kuzey Kırgızistan halkının çoğunun Doğu Türkistan'a kaçışı) (Kara, 2011: 541).

İsyanların ilki 4 Temmuz 1916'da Hocent şehrinde ve Semerkant bölgesinde başlamıştır (İnan, 1928: 18). Şehirlerde toplanan yaklaşık 7 bin kişi Rus karakol binasının çevresini kuşatıp "zorunlu çalıştırma fermanına" uymayacaklarını haykırmışlardır. Karakol binasını kuşatan ve isyanı ateşleyenlerin ön saflarında B. Abdumedeminov, Dedebay Meşeripov, Yahyahan Karı Alimhanov gibi aydınlar ve toplum önderleri cesaretle yürümüşlerdir. Duruma tepki gösteren ve göstericilerin dağılması için harekete geçen Rus Güvenlik güçlerinin silahsız göstericiler üzerine açtıkları ateş sonucu üç gösterici öldürülmüş, aralarında Kırgız kanaat önderlerinden İşanhan Mirza Orınov`un da bulunduğu dört kişi de yaralanmıştır (Kara, 2011: 541).

Gösteriler artık kontrolden çıkmış Andican'a da sıçramış, isyana dönüşerek bölge genelinde hızla yayılmaya başlamış ve 15 Temmuz sonrası bütün Özbek toprağına yayılmıştır (Kara, 2011: 541-542). Hocent'te isyan başlatıldığı söylentisi hızla Türkistan topraklarında yayılmaya başlamıştı. Kuzey Kırgızistan 'dan yayılmaya başlayan isyan Bişkek uezdini, Oluya Ata (Evliya Ata) uezdini, dağlık bölgesi, Karakol uezdini ve güneyde Oş uezdini ile diğer bölgelere sıçramıştır (Kara, 2011: 542). Gösteri şeklinde başlayan isyanların öncesinde Tokmak ve Bişkek'te isyan hazırlık çalışmaları gizli olarak planlanmış, bölgedeki yerleşimci Ruslar dahil Rus güvenlik ve istihbarat birimlerinin haberi olmamıştır. Kırgızistan'ın hemen hemen bütün bölgelerinde hızla silahlı ayaklanmaya dönüşen isyan, Temmuz ayının sonunda, tüm bölgeye yayılmıştır. İsyancıların ilk hedefleri nahiye yöneticileri (özellikle geri hizmetler için liste hazırlayan görevliler), kabile şefleri ve çarlık yönetimi tarafından görevlendirilen diğer alt kademe yöneticiler olmuştur. Özellikle Narın ilçesinde başlatılan halk isyanları dikkat çekmiştir (Ziyayev, 2007: 380-381).

7 Ağustos'ta Pişpek ahalisi "Biz çar idaresinin zulmüne daha fazla dayanamayacağız!" "Zalimler bizim topraklarımızı ve hayvanlarımızı elimizden aldılar!" diye bağırmışlardır. İsyancılar azılı sömürge temsilcilerini döverek öldürmüşlerdir (Kara, 2011: 542).

Ayaklanmalar (1916 Temmuz-Ağustos ayındaki) bölgede çok geniş bir alanda başlasa da özünde tek elden yönetilmemiş, koordineli planlı olarak başlatılmamıştı. Önceden bölgedeki huzursuzlukları hisseden ve her türlü tedbiri alan Rus askeri yetkilileri ile Türkistan Genel Valisi Kuropatkin ve Bozkır Genel Valisi N. A. Suhomlinov tarafından Hive, Hocent, Cizak, Taşkent, Vernıy, Akmola şehirlerinde, Sır Derya, Yedi Su, Fergana bölgelerinde birbiri ardına başlayan ayaklanmalar, acımasızca ve kanlı bir 
şekilde bastırılmıştır. Ayaklanmalarda Rus Askeri birliklerinin yanı sıra silahlandırılmış ve eğitilmiş Rus yerleşimcilerine de görev verilmişti. Şubat ayına kadar süren kıyımda en çok mal ve can kaybını Yedi Su bölgesindeki Kırgızlar vermişti (Sagınbekov, 2007: 18).

İsyana karşı Ruslar; "Yerli halk bilmelidir ki, akıtılan Rus kanının intikamı, sadece suçluların asılması ile değil, arazilerinin müsadere edilmesi ile de alınacaktır" (Köylü, 2016: 132) düşüncesiyle hareket etmişler. Dolayısıyla isyancılara karşı sertliğin dışında zalimce müdahale etmişlerdir. İsyana karışıp karışmadığına bakmadan ve hiçbir yargılama yapılmadan isyan bölgesinde gördükleri ve şüphelendikleri kişileri yakaladıkları yerde katletmişlerdir. Kuropatkin, isyanı bastırmak üzere kurulan "cezalandırma birlikleri” adını verdiği infazcı askerlere 16 Ağustos 1916'da isyancıları buldukları yerde öldürülmelerini, başta atları, davarları olmak üzere tüm arazi ve mallarına ele koymalarını emrini vermişti (Köylü, 2016: 132).

Rus askerlerinin isyanı bastırmada kullandıkları zalimce ve insanlık onuruyla bağdaşmayan yöntemleri Kırgızları ürkütmüştü. Ellerindeki geleneksel kılıç, mızrak, topuz, balta gibi silahlar ve ateşli silah olarak eski tip tüfeklerle Rus askerlerinin elinde bulunan dönemin en yeni ateşli silahlarına ve savaş sanatı konusunda son derece eğitimli askerlerine karşı verdikleri mücadelede başarılı olmaları çok zordu. Dolayısıyla başa çıkamayacakları bu gücün karşısında canlarını ve götürebilecekleri kadar mallarını kurtarmanın tek yol vardı: Çin'e kaçmak. Ancak bu kurtuluş yolu da tam bir felaketle sonuçlanacaktır. Çünkü Çin`e kaçmak, Çin`de yaşamak ve Çin`den dönme süreci Kırgız Halkı için tam bir felaket olmuştur (Sagınbekov, 2007: 35-36).

Kırgız Halkı Çin`e kaçarken birçok dağ geçidi kullanmıştır. Kışın bastırmasıyla özellikle Çin in Üç Tufan ilçesine geçerken kullanılan Bedel geçidinde yanlarında götürdükleri binlerce hayvanları telef olmuştur. Kışın bastırması, otlakların ortadan kalkması, yanlarında götürdükleri hayvanların ağır koşullarda telef olmasıyla, kısa sürede açlık ve devamında hastalıklar baş göstermeye başlamış, yolda yürüyemeyen ve yolculuğa yük olarak görülen hasta ve yaşlılar geride ölüme terk edilmek zorunda kalınmıştır. Hatta o kadar zor durumda kalınmıştır ki, geçtikleri yerlerde bulunan yerli tüccarlara çalıştırılmak üzere 12 ve daha üzerinde bulunan kız ve erkek çocuklarını yok pahasına (30-40 Som) satmak mecburiyetinde kalmışlardır. Çin`e kaçmak sorunda kalanlar arasında hastalıklardan ve açlıktan ölenlerin sayısı hala tam olarak bilinmemektedir (Köylü, 2016: 135-136).

Çin`e 1917 Ocak ayında ulaşan Kırgız halkına, Çin yönetimi tarafından beklenen ilgi gösterilmediği gibi geriye dönmeleri için bask1 uygulanmaya başlanmıştır. Gelenlerin çoğunluğunun yolculuk esnasında mallarını kaybetmiş, fakirleşmiş, ayrıca bulaşıcı hastalıklar olmak üzere sağlık sorunları olan kimseler olarak görülmesi baskının nedeni olarak düşünülebilir. Ayrıca fakirleşen Kırgız Halkının çapulculuk ve yağma yaparak ilçelerinin güvenliğini ve huzurunu bozabilecekleri de düşünülüyordu. Kırgız halkının Çin`e kâr olmaktan çok, yük olacağı düşüncesi daha baskındı.

1917 Rus ihtilali bir kurtuluş gibi gözükse de Kırgız Halkı için vatanlarına dönüş, gelişlerinden daha büyük bir trajedi olmuştur. Çin`e göç esnasında atlarını ve hayvanlarını yolda kaybeden Kırgızlar dönüş yolculuğunda da kış şartları altında üzerlerindeki yetersiz kıyafetler ile donarak, bulaşıcı hastalıklar ve açlık yüzünden yolda ölmüşlerdir. Vatana dönmeyi başaran Kırgızlar, artık işgal edilmiş ve ellerinden alınmış evleri ve arazileriyle karşılaşmışlar, evsiz- barksız yoksulluk içinde kalanlar boğaz tokluğuna bölgedeki Rus ve Tatarlara hizmet etmek zorunda kalmışlardır. Diğer taraftan Kırgızların dönüşünü takip eden ve isyanda zarar gören Ruslar, köy köy dolaşarak bulabildikleri Kırgızları katletmişlerdir (Sagınbekov, 2007: 37).

Başta Karakol (Prjevalsk) Kazası olmak üzere isyanın en yoğun yaşandığı bölgelerde Kırgız Milli Kıyafeti Ruslar için "düşman” sembolü haline gelmiş, bu kıyafetle dolaşan Kırgızlar ölümle aynı anlamı taşımıştır. Katliam ve soykırım ancak 17 Şubat 1918'de Almatı'da Sovyet hükümeti kurulmasıyla sona ermiştir. Kırgızların bu korkunç kıyımdaki kayıpları ile ilgili Profesör O. İbraimov şu tespitlerde bulunur (Köylü, 2016: 136-137): 
Kırgız yazarları Aaalı Tokombaev ve Tölögön Kasımbekov'ların tahminlerine göre Ürkün'de yaklaşık 300.000 binden fazla Kırgız ailesi kırlmıştı. Eğer her bir ailede ortalama üç kişi diye varsaydı̆̆ımızda bile, bu sayı bir milyona yaklaşmaktadır. Fakat bilindiği gibi Orta Asya'da her iki aileden biri kalabalık sayllır. 1913 yılının istatistik verilerine göre her bir aile beşten fazla kişiden ibaretti. Karakol ve Pişpek kazalarında isyandan önce 62.340 aile var ise, 1917 Ocak ayında 41.975 aileye düşmüşür. Bu iki kaza halkının 214.072 kişiye azaldı̆̆ı anlamına gelmektedir. Başka kazalardaki kayıpları da buna eklersek muazzam bir rakamın ortaya çıkacă̆ kesindir.

Rusya'daki Ekim ihtilali ve sonra da Taşkent'teki silahlı ayaklanma sonrası Sovyet hükümeti, 1917'de ilk olarak Kırgızistan'ın güneyinde Sülüktü ve Kızıl Kıya kömür yataklarının bulunduğu bölgede, sonra da Talas'ta yoğunlaşmıştır. 1918 yılının Ocak-Şubat aylarında Bişkek kazasının, Nisan ayında Narın'ın, Mayıs-Haziran'da ise Karakol (Prjevalsk) şehirlerinin idaresi Sovyet Rusya'nın eline geçmiştir. 1918 yılının ortalarında Sovyet hükümeti Kırgızistan'ın bütün bölgelerine egemen olmuş ve böylece Kırgızistan'ın tarihinde yeni bir sayfa açılmıştır (Sagınbekov, 2007: 19).

Fakat Kırgızistan topraklarında Sovyet hükümetinin kurulması bir iç savaşa yol açmıştı. Kırgızistan'ın dağlık bölümlerindeki birçok yerleşim biriminde silahlı ayaklanmalar olmuşsa da bu ayaklanmalar kısa zamanda acımasızca bastırılmıştır. 1918'in sonbaharında artık bütün Kırgızistan toprakları Sovyet hükümetinin kontrolü altındaydı (Sagınbekov, 2007: 19).

\section{SONUÇ}

Ürkün İsyanı ve sonrasında Kırgız Türkleri için, bir çeşit soykırıma dönüşen isyanda yaşamını kaybeden, katledilen ve kaçarken hastalık, açlık, soğuktan donarak ölen Kırgız Türklerinin sayısı kesin bir rakama bağlanmamış olmasına rağmen araştırmacılar, dönemin kayıtlarını incelemesi neticesinde farklı da olsa tahmini bir sonuca ulaşmışlardır. Bu rakamlar 300 bin, bazılarına göre ise 274 bini bulmuştur (Kara, 2011: 544). İsyandaki Kırgızların kayıpları yanında Rusların kayıpları çok düşük kalmıştır.

Kayıların fazla olmasının sebepleri ayaklanmaların planlı ve organize bir şekilde tek merkezden yönetilmemesi, yeni silah ve teçhizatlarla donatılmış Rus askeri birliklerine karşı ilkel silahlarla savaşılması, yetersiz lojistik destek ve eğitimsiz isyancıların disiplinsiz hareket tarzları olmuştur. İsyanlar esnasında dağınık isyancılar ve aileleri Rus askerleri ve Rus silahlı yerleşimciler için kolay hedef haline gelmişlerdir. İsyanlara müdahalede acımasız ve zalimce yöntemlerin kullanılması, isyancıların gözlerinin korkmasına ve kısa sürede dağılmasına, kendilerini, ailelerini ve sürülerini korumak maksadıyla dağlara çekilmelerine neden olmuştur. İsyan başlangıcı yaz ayları olmasına rağmen isyanların uzaması nedeniyle savaşma yeteneğini kaybederek Çin`e kaçmaya başlayan isyancılar, yeterli kışlık kıyafet olmadan çıktıkları yolda, yüksek dağ geçitlerinde soğuk ve tipiyle oldukça fazla kayıp vermişlerdir. Sürülerini kaybetmeleri, soğuk, açlık ve bulaşıcı hastalıkların da etkisiyle kayıplar daha da artmıştır. 
Toros Üniversitesi İISBF Sosyal Bilimler Dergisi, 2021, 8(15)

Toros University FEASS Journal of Social Sciences 2021, 8(15)

Tablo 1. İsyan sırasında Kırgız ve Rus Kayıpları (Kara, 2011: 544):

\begin{tabular}{|l|l|l|l|l|l|l|l|l|}
\hline & $\begin{array}{l}\text { Ölen- } \\
\text { Kaybolan- }\end{array}$ & $\begin{array}{l}\text { Pişkek } \\
\text { Kırgızları }\end{array}$ & $\begin{array}{l}\text { IssıkgöI } \\
\text { Kırgızları }\end{array}$ & Çin & İdam & $\begin{array}{l}\text { Kürek } \\
\text { Cezası }\end{array}$ & $\begin{array}{l}\text { Islah } \\
\text { Evi }\end{array}$ & Hapis \\
\hline $\begin{array}{l}\text { 1913-1918 Arası } \\
\text { Nüfus Sayımına } \\
\text { Göre }\end{array}$ & $\begin{array}{l}203.803 \\
\text { Kişi }\end{array}$ & & & & & \\
\hline $\begin{array}{l}\text { Göçmenleri } \\
\text { Yerleştirme } \\
\text { Başkanlığına göre }\end{array}$ \\
\hline Şamşı̀da
\end{tabular}

Sonuçta, 1916 yılında başlatılan "Ürkün İsyanı” olarak geçen bu olay, Kırgız Halkının yüzlerce yıl sömürge altında yaşamaya karşı başlattığı "Milli Bir Kurtuluş Savaşı" olarak tarihe geçmiştir. İsyan, Kırgız halkını harekete geçiren Rus Çar'ının Kırgız erkelerinin cephe gerisinde çalıştırılması konusundaki seferberlik fermanı başta olmak üzere tarihsel süreç içerisinde gelişen üç köklü ihtilafın sonucu olarak ortaya çıkmıştır. Ancak isyanı ateşleyen her ne kadar seferberlik fermanı olsa da isyanın asıl nedeni yüzlerce yıllık Rus sömürgeciliğine karşı biriken nefret duygusuydu. Rus Yönetimi tarafından Kırgız halkına karşı uygulanan ağır vergiler ve zorunlu çalıştırma durumları ile Rus tüccarlar tarafından adilane olmayan bir şekilde belirlenen fiyatlar da isyana yol açmıştır.

SSCB dağıldıktan sonra Orta Asya bölgesinde, Kırgızistan'da, Kazakistan, Tacikistan, Özbekistan ve Türkmenistan'da yeni bir jeopolitik durum ortaya çıkmıştır. Bu ülkeler, Avrasya'da stratejik açıdan önemli birçok ülke ve bölge ile sınırlanmıştır. Bu yeni hal, Orta Asya'da çıkarları olan birçok devlet için pek tabii önemlidir. Çoğu ülke, çok farklı nedenlerle Orta Asya bölgesine ilgi göstermeye başlamıştır. Türkiye ile Orta Asya Cumhuriyetlerinden Kırgızistan ile ilişkilerini güçlendirmek, Kırgızistan'ın dünya sahnesindeki konumunu pekiştirmek için çok önemlidir. Türkiye ile ilgili bilimsel inceleme ve araştırmalara bakıldığında Türk dünyası ile ilginin başlangıç tarihinin Cumhuriyet'in ilk yılları olduğu görülmektedir. Nitekim Türkiye Cumhuriyeti'nin ilk yıllarından itibaren Türkiye'de daha yerleşik gelişmeler olduğu aşikardır ki Atatürk Anadolu bölgelerinin dışında ve bu konuyu yakından takip etmekte son derece hassastır:

"Bu dostumuz (Sovyetler Birliği) yönetiminde dili bir, inancı bir, bizim asli bir kardeşimiz var. Onlarla ilgilenmeye hazır olmalıyız. Hazır olmak yalnız o gün susmayı beklemek değildir. Hazırlamalısın. Milletler buna nasıl hazırlanmalı? Manevi köprülerini sağlam tutmak! Dil bir köprüdür... Inanç bir köprüdür... Tarih bir köprüdür...”

Atatürk'ün sağlığında yürütülen bu faaliyetler, ölümüyle uzun süre bir kenara bırakılmış, Sovyetler Birliği'nin dağıldığı yıllara kadar göz ardı edilmiştir. 


\section{KAYNAKÇA:}

Brower, D. (2003) Turkestan And The Fate Of The Russıan Empıre", New York.

Devlet, N. (1985). "The History of National Struggle of the Russian Turks (1905-1917)", TTK Yayınlar1, Ankara.

Djunushaliev, D. (2002). “Kırgızistan'da 1916 İsyanı”, Türkler, C.18, Ankara.

İbraimov, O. (1993). “Kızıl Kırgın”, Ürkün, Bişkek.

İnan, Abdülkadir. (1928). "1916 Senesi Türkistan Umum Kıyamı” Yeni Türkistan Dergisi, İstanbul.

Kara, F. (2011). "1916 Kırgız Büyük İsyanı: Ürkün”, Turkish Studies - International Periodical For The Languages, Literature and History of Turkish or Turkic Volume 6(2) Spring: 537-546.

Kodoman, B. (2012). "Causes of the Urkun: The Genocide of 1916", SDÜ Fen Edebiyat Fakültesi SDU Faculty of Arts and Sciences Sosyal Bilimler Dergisi Journal of Social Sciences, Ağustos, (26): 21-26.

Köylü, M. (2014). "Gurbetteki Vatan Kırgızistan, Ahıska’dan Fergana`ya Bir Sürgün ve Soykırım Hikayesi”, Astana Yayınları, Ankara.

Köylü, M. (2016). “Ürkün: Bir Katliamın Öyküsü”, Akademik İncelemeler Dergisi (Journal of Academic Inquiries) 11(2):117-141.

Sagınbekov, B. (2007). “Kırgızistan’da Ürkün Olayı ve Kırgız Şiirindeki Akisleri”, Yayınlanmamış Doktora Tezi, Ege Üniversitesi Sosyal Bilimler Enstitüsü Türk Dünyası Araştırmaları Anabilim Dalı Türk Dünyası Edebiyatları Bilim Dalı, İzmir. 